\title{
Når Guds engle er onde
}

\section{- En motivhistorisk undersøgelse af Jubilæerbogen, Sekthåndbogen og Damaskusskriftets forhold til Vægternes Bog}

\author{
Stud.theol. \\ Rikke Hvarregaard Andersen
}

\begin{abstract}
The aim of this article is to re-examine the claim that the Book of Jubilees and two Qumran texts, the Community Rule and the Damascus Document, have been influenced by the myth of the fallen angels as found in the Book of the Watchers. The analysis focuses on the problem of evil and examines of what sin consists, who is held responsible for it, and how human nature is understood. Even if dependence on the Book of the Watchers is likely, the motifs have undergone radical changes in the three other texts, and it would be more precise to describe the influence as limited.
\end{abstract}

Keywords: Sin - apocalyptic - fallen angels - the Book of the Watchers - the Book of Jubilees - Mastema - evil inclination - the Two Spirits doctrine - the Community Rule - the Damascus Document - Belial.

I den antikke jødedom var synd en central problemstilling. Man søgte ikke kun efter en klar definition på syndens beskaffenhed, men var ligeledes optaget af at betone ansvaret for den. Ansvarsplaceringen var nøje forbundet med menneskesynet, der var udslagsgivende for det guddommelige og det menneskelige forhold. Problemstillingen blev søgt besvaret på forskellige måder, og perioden kunne derfor opvise en bred diversitet af forklaringer. Ifølge Collins kan disse opdeles i fem kategorier:

Myten om de faldne engle

Myten om Adam og Eva

Ideen om de to ånder

Menneskets onde tilbøjelighed

Ondskab ligestillet med urkaos ${ }^{1}$

1. John J. Collins, "The Origin of Evil in Apocalyptic Literature and the Dead Sea Scrolls", Seers, Sybils, and Sages in Hellenistic-Roman Judaism, JSJSup 54 (Leiden: Brill 1997), 287-99 (292-98); Annette Yoshiko Reed, Fallen angels and the history of Judaism and Christianity. The Reception of Enochic Literature (Cambridge: Cambridge University Press 2005), 101. 
Karakteristisk for myten om de faldne engle og ideen om de to ånder er, at de begge henviser til eksterne magter, der påvirker mennesket. De placerer mennesket inden for en kosmologisk ramme, hvor ydre instanser fungerer som en nærværende trussel, der sætter både den enkelte og menneskeheden under pres.

Første Enoksbog er en sammenvævning af flere jødiske tekster og opdeles normalt i fem enheder. Englefaldet er indeholdt i den første del, der spænder fra kap. 1 til 36 og betegnes Vægternes Bog. Inden for forskningen mener man, at denne tekst har været inspirationskilde for Jubilæerbogen samt for Sekthåndbogen og Damaskusskriftet, der sandsynligvis stammer fra Qumranmenigheden. Det er særligt James C. VanderKam, der har plæderet for et litterært afhængighedsforhold mellem Første Enoksbog og Jubilæerbogen. ${ }^{2}$ Han argumenterer for, at Jubilæerbogens forfattere har kendskab til flere af værkets enheder (heriblandt Vægternes Bog) samt traditioner om Enok - en hypotese, som efterfølgende er blevet kritiseret. ${ }^{3}$ Spørgsmålet om litterær afhængighed er vanskeligt at afklare, hvilket kan illustreres ved van Ruiten og Segal, der begge har sammenlignet 1 En 10-11 og Jub 5. Hvor van Ruiten fokuserer på forskellene mellem de to tekstperikoper og argumenterer for, at de bygger på den samme tradition, som de uafhængigt af hinanden har bearbejdet, så fremhæver Segal lighederne og konkluderer, at Jub 5 er afhængig af 1 En 10-11 (van Ruiten 2000, 197; Segal 2007, 116).

2. James C. VanderKam, "Enoch Traditions in Jubilees and Other Second-Century Sources", SBLSP 13 (1978), 229-51 (231-41); James C. VanderKam, Enoch and the Growth of an Apocalyptic Tradition, CBQMS 16 (Washington, DC: The Catholic Biblical Association of America 1984), 179-88. Se derudover: J. T. Milik, The Books of Enoch. Aramaic Fragments of Qumran Cave 4 (Oxford: The Clarendon Press 1976), 24-25; Paolo Sacchi, Jewish Apocalyptic and its History, JSPSup 20 (Sheffield: Sheffield Academic Press Ltd 1990), 63-64; George W. E. Nickelsburg, 1 Enoch. A Commentary on the Book of 1 Enoch Chapters 1-36; 81-108 (Minneapolis: Hermeneia/Fortress Press 2001), 71-76; Michael Segal, The Book of Jubilees. Rewritten Bible, Redaction, Ideology and Theology (Leiden/Boston: Brill 2007), 115-16; Loren T. Stuckenbruck, The Myth of Rebellious Angels, WUNT 335 (Tübingen: Mohr Siebeck 2014), 24-25; Helge Kvanvig, Primeval History. Babylonian, Biblical, and Enochic (Leiden: Brill 2011), 493-94.

3. Jacques T.A.G.M. van Ruiten, Primeval History Interpreted. The Rewriting of Genesis 1-11 in the Book of Jubilees, JSJSup 66 (Leiden: Brill 2000), 197; Jacques T.A.G.M. van Ruiten "A Literary Dependency of Jubilees on 1 Enoch", Enoch and Qumran Origins. New Light on a Forgotten Connection, red. Gabriele Boccaccini (Grand Rapids/Cambridge: Wm. B. Eerdmans Publishing Co. 2005), 90-93; John S. Bergsma, "The Relationship between Jubilees and the Early Enochic books", Enoch and the Mosaic Torah. The Evidence of Jubilees, red. Gabriele Boccaccini \& Giovanni Ibba (Grand Rapids/Cambridge: Wm. B. Eerdmans Publishing Co. 2009), 36-51 (45-51). 
Det forholder sig anderledes med Første Enoksbog og teksterne fra Qumran, eftersom der er fundet aramæiske fragmenter af Vægternes Bog m.fl. blandt Dødehavsskrifterne, og dens indflydelse på menighedens teologi virker derfor sandsynlig. ${ }^{4}$ Tekststykkerne er dog meget fragmentariske, hvilket vanskeliggør arbejdet med dem. De korrelerer ikke altid med de senere udgaver på græsk og etiopisk, hvilket kunne tyde på, at det er en tidligere (og længere) udgave af Vægternes Bog, som menigheden kendte. Derudover var Qumranmenigheden påvirket af teologier fra andre tekstsamlinger, der ligesom Første Enoksbog rummer et apokalyptisk verdensbillede. ${ }^{5}$

Litterær afhængighed udelukker ikke en bearbejdelse af materialet, så at teksternes teologiske pointer ikke altid stemmer overens med dem, som Vægternes Bog indeholder. Dette har VanderKam også for øje, når han sammenligner Vægternes Bog og Jubilæerbogen. ${ }^{6}$ Til trods for de markante forskelle kan man i forskningslitteraturen finde forholdet mellem de to tekster beskrevet med "heavy dependence", og at Jubilæerbogen "draw heavily" på materialet i Vægternes Bog (Reed 2005, 118; Kvanvig 2011, 494). Det samme gør sig gældende, når Alexander taler om, at tekstens ideer blev "totally integrated" i Qumranmenighedens verdenssyn (Alexander 1999, 351). Af denne grund $ø$ nker jeg at efterprøve indflydelsen fra Vægternes Bog, fordi jeg vil vise, at Jubilæerbogen, Sekthåndbogen og Damaskusskriftet på afgørende punkter tager afstand fra dens konklusioner. Min vinkel på teksternes forhold til Vægternes Bog er motivhistorisk, idet jeg tager

\footnotetext{
4. Milik 1976, 22-41; Peter W. Flint, "Apocrypha, Other Previously-Known Writings, and Pseudepigrapha in the Dead Sea Scrolls", The Dead Sea Scrolls after Fifty Years, red. Peter W. Flint \& James C. VanderKam (Leiden/Boston/Köln: Brill 1999), 24-66; Philip S. Alexander, "The Demonology of the Dead Sea Scrolls", The Dead Sea Scrolls after Fifty Years, red. Peter W. Flint \& James C. VanderKam (Leiden/Boston/Köln: Brill 1999), 331-53 (337); Archie T. Wright, The Origin of Evil Spirits. The Reception of Genesis 6:1-4 in Early Jewish Literature, WUNT 2. Reihe 198 (Tübingen: Mohr Siebeck 2013), 169-70.

5. Loren T. Stuckenbruck, "The Early Traditions Related to 1 Enoch from the Dead Sea Scrolls. An Overview and Assessment”, The Early Enoch Literature, red. Gabriele Boccaccini \& John J. Collins, JSJSup 121 (Leiden/Boston: Brill 2007), 41-63 (63); John J. Collins, "Enochic Judaism and the Sect of the Dead Sea Scrolls", The Early Enoch Literature, red. Gabriele Boccaccini \& John J. Collins, JSJSup 121 (Leiden/Boston: Brill 2007), 283-299 (296; 298).

6. Se fx: James C. VanderKam, "The Angel Story in the Book of Jubilees", Pseudepigraphic Perspectives. The Apocrypha and Pseudepigrapha in light of The Dead Sea Scrolls, red. Esther G. Chazon \& Michael Stone (Leiden: Brill 1999), 151-70. Se derudover: Ida Fröhlich, "Enoch and Jubilees", Enoch and Qumran Origins. New Light on a Forgotten Connection, red. Gabriele Boccaccini (Grand Rapids/Cambridge: Wm. B. Eerdmans Publishing Co. 2005), 141-147; Maxwell J. Davidson, Angels at Qumran. A Comparative Study of 1 Enoch 1-36, 72-108 and Sectarian Writings from Qumran, JSPSup 11 (Sheffield: JSOT Press 1992), 320-22.
} 
udgangspunkt i synd som en bestemt teologisk grundtanke og klarlægger følgende aspekter: syndens beskaffenhed, placering af ansvar herfor og menneskesynet. Herudfra vil jeg undersøge, om der foreligger et motivhistorisk afhængighedsforhold. Ved en sammenlignende undersøgelse af 1 En 6-11, Jub 4-5; 7, 1QS 3-4 og Damaskusskriftet $ø n s k e r$ jeg at vise, at selvom der sandsynligvis eksisterer et litterært afhængighedsforhold af Vægternes Bog, så er der i teksterne foretaget gennemgribende teologiske ændringer. De indeholder tankegange, som er Vægternes Bog fremmed, og dens indflydelse på teksternes syndsopfattelser er derfor begrænset.

\section{Myten om de faldne engle i 1 En 6-11}

1 En 6-11 indeholder et verdensbillede, hvor synden er brudt ind i den jordiske sfære ved himmelske magter. Urhistorien tager således ikke sin begyndelse ved skabelsen, men griber derimod tilbage til den episode i den antediluvianske tid, hvor engle overtræder den guddommelige orden.

De gængse forskningsteorier betragter 1 En 6-11 som bestående af flere traditionslag med forskellige indholdsbestemmelser af synden og de hovedansvarlige herfor. ${ }^{7}$ I det ældste lag betegnes Semjaza som anfører for engleskaren, hvis overtrædelse består i seksuel omgang med menneskekvinderne. Konsekvensen heraf bliver fødslen af kæmper, der fungerer som katalysatorer for vold og ødelæggelse på jorden. ${ }^{8}$ I det yngre lag er det derimod Azazel, der virker som hovedaktør for syndens opståen. Han bringer forbudt lærdom til menneskene, hvilket afstedkommer deres korrumpering. Vidensaspektet findes dog også i forbindelse med Semjaza-narrativet - nærmere bestemt i 7,$1 ; 8,3 ; 9,8 ; 10,7$ - men Nickelsburg betragter dette som et sekundært motiv, der blev inkorporeret ved sammenvævningen af de to

7. Dimant argumenterer for tre traditionslag. Jeg følger Nickelsburg, der går ud fra to traditionslag med redaktionelle bearbejdelser, jf. D. Dimant, "1 Enoch 6-11. A Methodological Perspective", SBLSP 13 (1978), 323-39 (329); George W.E. Nickelsburg, "Apocalyptic and Myth in 1 Enoch 6-11", JBL 96 No. 3 (1977), 383405 (386-89).

8. Azazel nævnes som en af de nedstegne engle. Navnet gengives forskelligt i det foreliggende traditionsmateriale, men der er alligevel mulighed for at opfatte englen i 6,7 og 8,1 som den samme, jf. Matthew Black, The Book of Enoch or I Enoch. A New English Edition with Commentary and Textual Notes, SVTP 7 (Leiden: Brill 1985), 121. 
mytestrata. ${ }^{9}$ Hans argumentation går på, at motivet ikke udfylder en funktion i den grundlæggende fortællestruktur: engle tager kvinder som hustruer $\rightarrow$ fremavling af kæmper $\rightarrow$ kæmpernes ødelæggelse af jorden (Nickelsburg 1977, 385). ${ }^{10}$ Der foreligger således en observerbar spænding mellem traditionslagenes behandling af englefaldet.

Synden fremstilles som et udefrakommende element, der først når jorden ved englenes nedstigning. Deres seksuelle omgang med kvinderne er en overtrædelse af den gudgivne orden, hvorfor kæmperne som resultat er onde ifølge deres natur. Netop ved selv at være en krænkelse udsætter de den skabte orden for yderligere overgreb (1 En 2,1; 15,3-7; Stuckenbruck 2014, 14-15). Synden består følgelig af denne naturstridige fremavling, hvor menneskene tildeles offerrollen, mens skylden mestendels er placeret hos Semjaza og engleskaren. Da syndfloden sendes som respons på kæmpernes ødelæggelser, rammes menneskene også, selvom hovedsigtet ikke er deres overtrædelser. Dette tydeliggøres ved strafudmålingen i 10,4-15, der er møntet på englene og deres afkom, hvilket ligeledes understreges i 13,4, hvor Enok fungerer som mægler mellem Gud og de strafskyldige engle (Davidson 1992, 55). Efter syndfloden opstår onde ånder fra de døde kæmper, og disse forleder menneskene. På den måde opfattes jorden som en arena, hvor onde ånder har frit spil, men det er et midlertidigt virke, eftersom teksten anvender en Urzeit-Endzeit typologi (1 En 16,1; Nickelsburg 2001, 270).

I modsætning til det ældste traditionslag tildeles menneskene et større ansvar i Azazel-narrativet, eftersom de praktiserer den fremmede lærdom. De fremstilles ikke som ofre for jordens ødelæggelse, men er medvirkende faktorer dertil. Azazel unddrager sig i den forbindelse ikke skyld, hvilket udpensles i 10,4-8. Indholdet af de forbudte kundskaber drejer sig om metallurgi, som muliggør menneskenes våbenfremstilling og deres deraf følgende voldshandlinger. Derudover tager også udarbejdelsen af smykkegenstande og kosmetik sin begyndelse (1 En 8,1; ibid., 190).

Vægternes Bog er bevaret i to græske overleveringer, henholdsvis Panopolis (GrPan) og Syncellus (GrSyn). Sidstnævnte indeholder en længere læsemåde af 8,1-2, der ikke findes i den etiopiske tekst (og

\footnotetext{
9. Reed opfatter ikke undervisningsmotivet som sekundært, men mener derimod, at det spiller en vital rolle i Semjaza-narrativet og derfor oprindeligt hører dertil. Motivet er dog blevet forandret i den redaktionelle proces, hvor Azazel-narrativet er blevet tilknyttet, jf. Reed 2005, 34.

10. Collins påpeger faren ved at betragte en tekst som 1 En 6-11 ud fra et litterærkritisk og formkritisk ønske om klarhed, der svarer til moderne idealer for en komposition, jf. John J. Collins, "Methodological Issues in the Study of 1 Enoch. Reflections on the articles of P. D. Hanson and G. W. Nickelsburg", SBLSP 13 (1978), 315-22 (315-16).
} 
heller ikke i GrPan eller de aramæiske fragmenter), og konsekvenserne af Azazels lære divergerer derfor i de to overleveringer. I den etiopiske tekst står følgende: "1 Azazel lærte menneskene at lave sværd og knive og skjolde og brystharnisker, og han viste dem, som kommer efter, brugen af armbånd og prydelse og brugen af øjenskygge og at forskønne øjenvipper og alle slags værdifulde og udvalgte sten og alle slags farvestoffer og alkymi. 2 Der var stor og megen ugudelighed, og de bedrev hor og syndede og ødelagde alle deres veje." 11 GrSyn tilføjer i slutningen af 8,1: “...og de begik overtrædelser og forledte de hellige”. Hans lære og menneskenes brug deraf fører altså de andre engle til fald. Der kan i denne forbindelse henvises til 1 En 86-89, hvor en genfortælling af myten forekommer. I beskrivelsen af englefaldet anvendes metaforer, og englene er repræsenteret ved stjerner. Den første begivenhed er faldet af en enkelt stjerne (= Azazel), hvorpå flere stjerner følger. På jorden forvandles de til tyre, der opsøger og bedækker køer (= kvinder), hvorfor synden heri er den seksuelle perversion, og der knyttes ikke forbudt lærdom til Azazel eller de andre engle. Nickelsburg finder i 1 En 86-89 støtte for ordlyden i GrSyn, men der er tydeligvis ikke en komplet overensstemmelse mellem Azazelnarrativet og denne genfortælling, eftersom den er selektiv i sin brug af det foreliggende traditionsmateriale (Nickelsburg 1977, 397-98). At Azazel foretager nedstigningen som den første engel i 1 En 86-89 bestyrker ikke nødvendigvis, at GrSyn indeholder den oprindelige ordlyd. I stedet for kan man betragte 1 En 86-89 som en genfortælling, der udnytter de mangefacetterede tolkningsmuligheder, som sammenvævningen af de to traditionslag åbner for. Ligeledes kan den længere læsemåde opfattes som en tilføjelse med moraliserende islæt. Hvis GrSyn lægges til grund, sker der en forskydning af forførelsesaspektet, og det er nu kvinderne, der agerer forførersker overfor englene og ikke omvendt. På den måde skal 8,1-2 læses som et flashback ${ }^{12}$ til de beskrevne begivenheder i 6-7, hvilket stemmer overens med 9,6-10, hvor ærkeenglene først opremser Azazels gerninger og derpå Semjazas (Reed 2005, 35-37; 61; 75; Black 1985, 127).

Vidensaspektet indeholder yderligere kundskaber, og i Semjazanarrativet i 8,3 underviser han og fem andre engle i magi og spådom, mens den samlede engleskare ligeledes åbenbarer magiske beskæfti-

11. Jeg gør brug af egne oversættelser og anvender: R. H. Charles (red.), The Ethiopic version of the Book of Enoch (Oxford: The Clarendon Press 1906). Se derudover: E. Hammershaimb et al. (red.), De gammeltestamentlige Pseudepigrafer (København: Det Danske Bibelselskab 2001); James H. Charlesworth (red.), The Old Testament Pseudepigrapha (Peabody, MA: Hendrickson 2013).

12. Hvis 8,1-2 skal forklares som et flashback, er det nødvendigt at opfatte Azazel i 6,7 og 8,1 som to forskellige engle. 
gelser i 7,1 til deres hustruer. Der forekommer følgelig en kontrast mellem de faldne engles instruktioner og den viden, som Enok opnår ved ærkeenglenes hjælp i 17,1-20,7, hvor indsigt i bl.a. himmellegemerne tillægges stor værdi (Stuckenbruck 2014, 14). Englene fungerer således som kulturbringere, hvis lærdom er negativt konnoteret og anført i Toraen som forbudt (Deut 18,9-14).

Menneskenes ondskab er en konsekvens af englenes handlinger, og selvom betoningen af skyld varierer i de to traditionslag, så opereres der mere eller mindre med et forsvar for mennesket. Den apokalyptiske tænkning er præget af et deterministisk verdenssyn, hvor de overjordiske magter er hovedaktørerne, der igangsætter begivenheder både i og uden for det menneskelige univers. Mennesket er derimod en passiv størrelse og afhængig af guddommelig indgriben. Umiddelbart frikendes Gud for syndens komme, men i 9,5-11 fremsætter ærkeenglene en bøn, hvor både hans alvidenhed og mangel på handling kommenteres (Nickelsburg 1977, 387; 389; Davidson 1992, 159). En understregning af det ondes problem er således en inkorporeret del af teksten selv, idet den efterlyser klare tegn på Guds vilje og styring af verdensforløbet. Guds indflydelse markeres først og fremmest ved den anvendte Urzeit-Endzeit typologi, der sætter en grænse for åndernes virke. Udover denne indskrænkning er der indlemmet andre indikatorer på, at verdensforløbet kontrolleres af Gud. Det anføres i 10,12 , at englene vil sidde fanget i 70 generationer, hvilket viser, at historien forløber efter en guddommelig plan, og dette markeres endvidere i 27,2-3, hvor Enok får anvist stedet for den sidste dom. Ydermere understreger anvendelsen af ærkeenglene, at ikke alle engle var involveret i faldet, men at der endnu er dem, der virker efter Guds vilje (1 En 10,15; ibid., 51-53; 297-98).

Et omstridt punkt er, hvorvidt englefaldet i 1 En 6-11 anvendes som forklaring på syndens oprindelse. Brand mener ikke, at myten omhandler dette aspekt, men at den udelukkende belyser syndflodens komme. ${ }^{13}$ Goff argumenterer for det samme og fremhæver derudover, at tekstens fokus ikke er syndens oprindelse, men derimod, hvorledes synden fortsætter sin tilstedeværelse i verden ved de onde ånder. Det er ikke muligt at bestemme syndens oprindelse nærmere, eftersom teksten ikke tydeliggør, hvorvidt synden allerede eksisterede i verden før englenes nedstigning. ${ }^{14}$ Et problem ved denne udlægning er, at den overser en central pointe i teksten. Det er netop igennem de

13. Miryam T. Brand, Evil Within and Without. The Source of Sin and Its Nature as Portrayed in Second Temple Literature, JAJSup 9 (Göttingen: Vandenhoeck \& Ruprecht 2013), 162; 167.

14. Matthew Goff, "Enochic Literature and the Persistence of Evil. Giants and Demons, Satan and Azazel", Das Böse, der Teufel und Dämonen - Evil, the Devil, and 
faldne engle, at menneskene lærer at synde, hvorfor de ikke kan begå overtrædelser, førend de er blevet instrueret deri (Davidson 1992, 47). Suter argumenterer for, at myten fungerer som paradigme på et syndigt præsteskab, idet teksten er optaget af renhed. Dermed er mytens fokuspunkt først og fremmest englene og deres skæbne. ${ }^{15}$ Som modsvar herpå kan der henvises til 10,16-22, der omhandler genoprettelsen af jorden, og menneskenes skæbne er derfor i lige så høj grad (eller måske endnu mere) tekstens kerne. 1 En 6-11 er en mangefacetteret perikope, hvilket besværliggør en entydig udlægning, men teksten forhindrer ikke en forståelse af englefaldet som syndens oprindelse. Ondskab kan ikke forklares ved menneskelig handlen alene, men må knyttes til mægtigere instanser, hvilket tydeliggør den underlegne stilling, som mennesket indtager i verden (Wright 2013, 130; Davidson 1992, 44; 47-48; 193; Reed 2005, 80; 100).

Sammenfatning: 1 En 6-11 består af to traditionslag, der indeholder myten om de faldne engle som forklaring på syndens oprindelse. Den dominerende indholdsbestemmelse af synden i det ældste traditionslag er englenes seksuelle overtrædelser, som resulterer i kæmpernes fremavling. Skylden er placeret hos englene og deres afkom, og synden fortsætter sin tilstedeværelse på jorden, eftersom onde ånder opstår fra de døde kæmper. I det yngste traditionslag består synden af Azazels lære, som han bringer til menneskene. Menneskene bliver her delagtige i skylden, fordi de praktiserer den fremmede lærdom. De to traditioner opererer dog begge ud fra en deterministisk forståelse af verden, hvor menneskene er underlagt de overjordiske magter.

\section{Myten om de faldne engle i Jub 4-5; 7}

Jubilæerbogen kan betegnes som Rewritten Scripture ${ }^{16}$, og dens udgave af englefaldet afviger på afgørende punkter fra den version, som

Demons, red. Jan Dochhorn m.fl., WUNT 2. Reihe 412 (Tübingen: Mohr Siebeck 2016), 43-57 (43-45).

15. David Suter, "Fallen Angel, Fallen Priest. The Problem of Family Purity in 1 Enoch 6-16", HUCA 50 (1979), 115-35 (122-24; 131). Himmelfarb mener, at himlen skal forstås som et tempel i Vægternes Bog. Teksten opererer med ideen om et himmelsk tempel, hvis præsteskab bryder de hellige forordninger ved at indgå ægteskab - en problematik, der højest sandsynligt skal spejle forfatterens tid, jf. Martha Himmelfarb, "Apocalyptic Ascent and the Heavenly Temple", SBLSP 26 (1987), 210-17 (210-11); Martha Himmelfarb, A Kingdom of Priests. Ancestry and Merit in Ancient Judaism (Philadelphia: University of Pennsylvania Press 2006), 21. 16. Sidnie White Crawford, Rewriting Scripture in Second Temple Times. Studies in the Dead Sea Scrolls and related literature (Grand Rapids/Cambridge: Wm. B. 
er indeholdt i 1 En 6-11. Myten er kun et centralt tema i få kapitler (dvs. i 4, 5 og 7) og får derfor ikke samme betydning for teksten, som den derimod har for Vægternes Bog (VanderKam 1999, 154).

En markant forskel til 1 En 6-11 er motivet for englenes nedstigning. De sendes af Gud med henblik på at undervise menneskene i ret og retfærdighed, og deres intentioner er derfor gode (Jub 4,15). Dette ændrer sig først på jorden, hvor de efter flere års ophold har samleje og avler kæmper med menneskekvinderne (Jub 5,1). Ved at understrege englenes oprindelige intentioner fremstilles de ikke som onde, men har større lighedstræk med vildfarne mennesker (Collins 1997, 291). I 1 En 6-11 beslutter englene allerede $i$ himlen, at de vil opsøge kvinderne, hvilket de sværger på. Når englenes overtrædelser flyttes, bevares den kosmiske balance, idet jorden og himlen holdes som skarpt adskilte størrelser, og sidstnævnte kommer ikke i kontakt med synden (Stuckenbruck 2014, 26).

En central antitese i Jubilæerbogen er renhed/urenhed, hvilken løber som en rød tråd gennem hele værket (Fröhlich 2005, 146). Dette markeres bl.a. ved de kultiske aktiviteter, som englene udfører i himlen. Eksempler herpå er fejring af ugefesten og omskærelse (Jub $6,17-18 ; 15,27-28) .{ }^{17}$ På den måde skaber teksten parallelitet mellem englene og Israel, eftersom førstnævnte overholder og praktiserer de forordninger, som sidenhen bliver Israels særegne identitetsmarkører i pagtsforholdet til Gud. Dette åbner for en opfattelse af himlen som et tempel og englene som præster, der fungerer som prototype på det jordiske tempel og den kult, som skal praktiseres der. ${ }^{18}$ Jubilæerbogens forskydning af englenes overtrædelser er derfor motiveret af et ønske om at skærme himlen og Gud fra synden (VanderKam 1999, 155). ${ }^{19}$

Eftersom menneskene skal undervises i ret og retfærdighed, forudsætter teksten, at synden allerede eksisterer på jorden inden englenes ankomst. Englefaldet i Jub 4-5; 7 er blot en enkelt ud af fem fortællinger, der alle berører spørgsmålet om synd, og VanderKam mener, at myten om Adam og Eva figurerer som den bagvedliggende forkla-

Eerdmans Publishing Co. 2008), 12-13; 62; 66.

17. Jacques van Ruiten, "Angels and Demons in the Book of Jubilees", Angels. The Concept of Celestial Beings - Origins, Development and Reception, red. Friedrich V. Reiterer m.fl. (Berlin/New York: Walter de Gruyter 2007), 585-609 (591-93).

18. Himmelfarb påpeger, at opfattelsen af himlen som et tempel kun er underforstået i Jubilæerbogen, jf. Martha Himmelfarb, "The Book of Jubilees and Early Jewish Mysticism", Enoch and the Mosaic Torah. The Evidence of Jubilees, red. Gabriele Boccaccini \& Giovanni Ibba (Grand Rapids/Cambridge: Wm. B. Eerdmans Publishing Co. 2009), 384-94 (390-91; 393-94).

19. Segal argumenterer for, at forskydningen af englenes overtrædelser udelukkende er kronologisk motiveret, jf. Segal 2007, 126-32. 
ring på englenes sendelse (VanderKam 1978, 244). Problemet med denne opfattelse er, at myten om Adam og Eva i 3,17-26 ikke omhandler syndens oprindelse. Den belyser derimod, hvordan visse træk ved verden blev til, $\mathrm{fx}$ hvorfor dyr ikke kan tale. ${ }^{20}$ Episoden om Adam og Eva som forklaring på oprindelig synd er en senere tolkning, der først vinder popularitet i det 1. årh. e.Kr. (Reed 2005, 52-53).

Englefaldet beskriver for det første årsagen til syndfloden. Kæmperne spreder kaos på jorden og drager menneskene med ind $\mathrm{i}$ deres ødelæggende gerninger, hvorfor de betragtes som medskyldige i, at synden spredes. Jubilæerbogen får på denne måde begrundet den straf, som i 1 En 6-11 fremstår uretfærdig, idet syndfloden var rettet mod kæmperne, men ligeledes ramte menneskene. For det andet placerer englefaldet synd inden for den guddommelige orden. Ondskaben fortsætter sin tilstedeværelse på jorden ved ånder, der bliver til som en følge af englene (Jub 10,5). De bliver anført af Mastema - en ond engel, som ikke regnes blandt de nedstegne engle, for de sidder på dette tidspunkt indespærret (Jub 5,6-11; Bergsma 2009, 48; Stuckenbruck 2009, 305; Alexander 1999, 341). Noa fremsætter en bøn om, at ånderne lægges i lænker, men Mastema protesterer i 10,8 med følgende begrundelse: “...for hvis der ikke efterlades mig nogen af dem, kan jeg ikke udøve min viljes herredømme over menneskenes børn. For de er sat til at ødelægge og krænke før min dom, for menneskenes børns ondskab er stor." ${ }^{21}$ Gud lader derpå en tiendedel af ånderne leve, der nu kan fortsætte deres virke, hvilket er en betydelig indskrænkning, som ikke finder sted i 1 En 6-11. ${ }^{22}$ På den måde gør teksten brug af en kosmisk modstander med mandat fra Gud, der er sat til at forlede menneskene. Mastema minder i høj grad om den satanfigur, som bl.a. optræder i Jobs Bog, og i Jub 10,11 anvendes betegnelsen "satan" også om ham (Alexander 1999, 342; Segal 2007, 176-77). Ånderne får i Jubilæerbogen en plads i den guddommelige orden og fremstilles ikke længere som en magtfaktor, der modarbejder Guds vilje. Kontrollen er derfor genoprettet, især ved det faktum at Mastemas virke skal forstås inden for en Urzeit-Endzeit typologi

20. Loren T. Stuckenbruck, "The Book of Jubilees and the Origin of Evil”, Enoch and the Mosaic Torah. The Evidence of Jubilees, red. Gabriele Boccaccini \& Giovanni Ibba (Grand Rapids/Cambridge: Wm. B. Eerdmans Publishing Co. 2009), 294308 (296-97).

21. James C. VanderKam (red.), The Book of Jubilees. A Critical Text, CSCO 510 (Louvain: Peeters 1989). Se derudover: Hammershaimb et al. 2001; Charlesworth 2013.

22. Brand påpeger, at teksten indeholder ideen om en syndscyklus, idet begrundelsen for åndernes fortsatte virke går på menneskenes ondskab. De er indsat til at straffe syndige mennesker, men samtidig vil de lede menneskene ud i flere syndsgerninger, hvorved den enkelte ikke kan bryde dette mønster, jf. Brand 2013, 181. 
(Jub 10,9; 11,4-5; Stuckenbruck 2014, 30; Reed 2005, 94-95; Brand 2013, 180).

Gud efterlader ikke menneskene uden et værn mod de onde ånder, eftersom Noa får åbenbaret medicinske praksisser, der beskytter mod angreb (Jub 10,10.13). Dette står i kontrast til 1 En 6-11, hvor denne viden blev tilknyttet de faldne engle. I 7,20 videregiver Noa forordninger til sine sønner, og hvis de overholder dem, kan de ikke påvirkes af ånderne. Dette tegner et billede af en verdensopfattelse, hvor menneskene har fri vilje, idet de selv vælger, om de vil holde budene, men billedet er ikke entydigt. Som anført ovenfor må Noa bede om guddommelig hjælp, fordi hans efterkommere ikke har en chance mod ånderne. Jubilæerbogen forsøger at balancere mellem menneskelig ansvarlighed på den ene side og dæmoniske kræfter på den anden. Mastema og hans ånder forårsager synd, men menneskene kan undgå påvirkning deraf ved at gribe til den åbenbarede lægekunst eller overholdelse af budene (Brand 2013, 195; Stuckenbruck 2009, 303). Som tidligere nævnt spiller englefaldet kun en central rolle i Jub 4-5; 7, og Mastema har heller ikke en særlig markant plads. ${ }^{23}$ I Jub 11,1-6 er det menneskene selv, der synder, men ånderne opmuntrer dertil, hvorfor menneskene først skal begynde at synde, førend ånderne kan udøve deres indflydelse (Bergsma 2009, 49).

Udover den seksuelle perversion er instruktionsmotivet også en del af Jubilæerbogen, men til forskel fra 1 En 6-11 omhandler de forbudte kundskaber kun spådom og astrologi. En interessant detalje er i denne forbindelse, at lærdommen ikke er vævet sammen med englenes seksuelle overtrædelser i Jub 4-5; 7. Den er derimod en synd, som menneskene først får kendskab til flere generationer senere. Kainam finder den bevaret på stentavler, og følgerne bliver, at han indgår et blandet ægteskab, således at der bygges bro mellem instruktionsmotivet og den seksuelle overtrædelse (Jub 8,3; 8,5; Stuckenbruck 2014, 31; Reed 2005, 92-3).

Sammenfatning: Myten om de faldne engle anvendes ikke som forklaring på syndens oprindelse men belyser derimod årsagen til syndfloden og placerer synd inden for den guddommelige orden. Englene sendes af Gud for at undervise menneskene, og det er først på jorden, at de går imod hans vilje ved at avle kæmper med kvinderne. Udover den seksuelle perversion er instruktionsmotivet også en inkorporeret del af teksten. Menneskene regnes som medskyldige og straffes herfor med syndfloden. Efterfølgende fortsætter ondskaben på jorden ved Mastema og hans onde ånder, der udøver deres indflydelse på menneskene, hvis menneskene selv begynder at synde. Som et værn mod

23. Efter kap. 11 nævnes Mastema i 18,9-12; 48,1-4; 48,9-19. 
ånderne kan de overholde budene eller gøre brug af den åbenbarede lægekunst, hvorfor teksten ikke er entydig omkring fri vilje.

\section{Ideen om de to ånder i 1QS 3-4 og Damaskusskriftet}

Ideen om de to ånder er at finde i centrale tekster fra Qumran, og de faldne engle knyttes her ikke sammen med spørgsmålet om synd. Derimod træder enkeltstående repræsentanter for ondskaben ind på den kosmiske scene og virker efter Guds vilje, hvorved hans kontrol og herredømme cementeres (Reed 2005, 99).

Sekthåndbogen rummer både ideen om de to ånder og ideen om en indre tilbøjelighed i mennesket. Teksten opererer med to overjordiske ledere, der repræsenterer de stridende parter i en kosmisk kamp mellem det gode og det onde. Denne krig udkæmpes af Lysenes fyrste (שר אורים) (מלאך חושך), der begge er skabt af Gud, men hvor kun førstnævnte er allieret med ham (1QS 3,20-21.25). ${ }^{25}$ Gud er derfor hævet over de to indsatte magter, der begge har mandat fra ham, og teksten anvender ikke en ligeværdig, kosmisk modstander, hvorfor der er tale om en relativ og ikke absolut dualisme. Ved at anvende to engle som frontfigurer i denne kosmiske strid placeres Gud mere i baggrunden, men der hersker ingen tvivl om, at alting i verden er ordnet og forløber efter hans forudbestemte plan (Davidson 1992, 161-62; Brand 2013, 261-62). ${ }^{26}$

24. Florentino García Martínez \& Eibert J. C. Tigchelaar (red.), The Dead Sea Scrolls Study Edition, Vol. 1 (Leiden: Brill 1997). Se derudover: Bodil Ejrnæs, Mogens Müller \& Søren Holst (red.), Dødehavsskrifterne og de antikke kilder om essaerne (København: Anis 2003).

25. Det er usikkert, hvilke engle de to betegnelser dækker over. Et forslag går på henholdsvis ærkeenglen Mikael og Belial, hvor sidstnævnte har sin begrundelse i teksten selv, idet der henvises til "Belials herredømme" (בממשלת בליעל) i 1,18.23-24. Det interessante for denne artikel er ikke en præcis identifikation af de to magter, men derimod en belysning af deres rolle. Sekthåndbogen anvender antitetiske par, og de to engle har hver sit ansvarsområde - "retfærdighedens børn" (בני צדק) er underlagt Lysenes fyrste, mens "uretfærdighedens børn" (בני עול) er underlagt Mørkets engel. På den måde udmønter den kosmiske dualisme sig i en social dualisme i 3,20-21, idet menneskene opdeles i to grupperinger, jf. Davidson 1992, 145-48; Brand 2013, 259.

26. Selvom Gud har et overordnet sigte med verden, så er det ikke menneskenes oplevelse, eftersom deres liv er underlagt et modsætningsforhold. De er opdelt i to grupper, men de retfærdige unddrager sig ikke synd. Dette forhold skyldes, at Mørkets engel forleder dem i 3,21-22, til trods for at det netop var blevet fastslået, at de retfærdige var under Lysenes fyrste. Teksten forklarer dette ved at henvise til "Guds hemmeligheder" (רזי אל) i 3,23, hvorved den indeholder en eksplicitering af det misforhold, som det enkelte menneske oplever. Det er ikke muligt at komme 
Synd er et udslag af denne kosmiske spænding, hvor Mørkets engel og hans følgeskare af ånder leder menneskene i fordærv, hvilket cementeres i 3,18-24. I 3,25-4,14 glider den kosmiske opdeling over i en etisk dualisme, hvor der fokuseres på menneskelige kvaliteter, som enten står på lysets eller mørkets side. Her er det indre liv i spil, og der opstilles en liste over de træk, som de to ånder frembringer i mennesket, hvilket også er det tætteste, som teksten kommer på at bestemme syndens beskaffenhed (ibid., 264-65). Ideen om prædestination er central fra 4,15-26, hvor det fremhæves, at det enkelte menneske har en indlejret andel af de to ånder i sig. Denne spænding i menneskets indre opfattes som en midlertidig konflikt, idet Gud vil bringe ondskab til ophør ved tidernes ende. På den måde forklarer Sekthåndbogen ideen om en indre tilbøjelighed som en tilstand i mennesket, der har sin ydre årsag hos Mørkets engel og hans ånder, og det er et grundvilkår, som ingen kan undslippe. Denne forklaringsmodel belyser, hvorfor også de retfærdige lever i synd, men selvom de to ånder virker i alle mennesker, så er det forudbestemt, hvem der i sidste ende skal regnes til de retfærdige, og hvem der står tilbage hos de uretfærdige (1QS 4,25-26; ibid., 266-69; Davidson 1992, 296).

I denne verdensopfattelse kan mennesket umiddelbart ikke holdes ansvarligt for sine gerninger, eftersom det ikke er udstyret med et forsvar, der kan stå imod Mørkets engel og hans ånder. Derudover har det ikke mulighed for at påvirke, hvilken gruppering som det i sidste ende vil tilhøre. Menneskets stilling i verden er dog ikke fuldstændig entydig, for i 3,17-18 fastslår teksten, at Gud har skabt det med herredømme over verden. Ydermere forekommer der andre passager i teksten (fx 2,25-3,12; 5,1), som antyder, at mennesket har et reelt valg mht. dets levevis. Denne spænding kan indikere forskellige traditionslag i teksten, der ikke er blevet harmoniseret i den redaktionelle proces (ibid., 150; 159-60; 296; Brand 2013, 258).

Sekthåndbogen er en interessant tekst, fordi den sammenvæver ideen om de to ånder med ideen om en indre tilbøjelighed i mennesket. Denne facetterede syndsopfattelse divergerer fra 1 En 6-11, selvom begge tekster betragter jorden som en arena for overjordiske magter. Sekthåndbogen er i høj grad optaget af menneskets indre liv, og Wright påpeger, at teksten har overtaget verdensbilledet fra Vægternes Bog men har videreudviklet antropologien og de dæmoniske elementer (Wright 2013, 169-70). Udover de mange fund fra Første Enoksbog blandt Dødehavsskrifterne, så var Jubilæerbogen også stærkt repræsenteret og har haft stor indflydelse på Qumranmenig-

med en nærmere forklaring på, hvorfor Gud overlader de retfærdige til Mørkets engel, men det er et forhold, som menneskene kan observere og undre sig over, jf. Brand 2013, 260. 
hedens teologi. Størstedelen af fragmenterne fra Første Enoksbog dateres forholdsvist tidligt, og på den baggrund har Milik argumenteret for, at menigheden mistede interesse for teksten (Milik 1976, 6-7). Jubilæerbogens fragmenter har derimod en senere datering, hvorfor det ikke lader til, at teksten blev "glemt". Dette kan ikke afgøres til fulde ud fra det overleverede materiale, men Jubilæerbogen deler et centralt element med Qumranmenigheden, som ikke findes i 1 En 6-11. Onde ånder er vigtige i tekstens verdensbillede, og ligesom i Jubilæerbogen har Gud indsat en anfører for dem, hvorved deres funktion er en del af den guddommelige orden (Flint 1999, 46-48; 63; Davidson 1992, 29-30; 322).

Sekthåndbogen trækker ikke tråde til en antediluviansk tid, hvor synden for første gang kan observeres på jorden, men i stedet forklares verdens beskaffenhed ud fra den kosmiske kamp, som har været i gang siden menneskets skabelse, og som vil fortsætte indtil de sidste tider. Den dualistiske opfattelse af verden og mennesket, som Sekthåndbogen indeholder, harmonerer ikke med 1 En 6-11, for selvom den ligeledes gør brug af onde engle, så sidder de efter deres nedstigning indespærret indtil den sidste dom (Davidson 1992, 43; 296; 321; Reed 2005, 100).

En anden central tekst fra Qumran er Damaskusskriftet, hvori Belial ${ }^{27}$ virker imod menneskene. ${ }^{28}$ I 4,12-18 fremstilles han som den, der bringer menneskene til fald, og i 5,17-19 bekæmper han Lysenes fyrste i den kosmiske kamp mellem det gode og det onde. Herved anvendes der lig Sekthåndbogen en kosmisk dualisme, hvor den menneskelige verden påvirkes af overjordiske magter, og denne udmønter sig i en social dualisme mellem to grupperinger, henholdsvis sektmedlemmerne og dem, der står udenfor (CD 4,14-19; Davidson 1992, 183; Wright 2013, 175). I den kosmiske kamp påvirker de to instanser menneskenes ledere - Moses og Aron på den ene side og Jannes og hans bror på den anden side. Teksten får her belyst, hvorfor falske ledere, der virker imod de guddommelige bud, kan opnå succes. Eftersom Damaskusskriftet henviser til Belial som den overjordi-

27. Belial er nævnt en enkelt gang i Jubilæerbogen, nærmere bestemt i 1,19-21, hvor han forleder og anklager Israel foran Gud. Damaskusskriftets forfattere har kendskab til Jubilæerbogen, idet der henvises til teksten i 16,2-4. Brand foreslår, at Damaskusskriftet kunne have forsøgt at harmonisere Mastema og Belial fra Jubilæerbogen til en enkelt figur, jf. Brand 2013, 225; Flint 1999, 65.

28. Damaskusskriftet indeholder egentlig to syndsopfattelser, hvor den anden omhandler menneskets indre tilbøjelighed. Collins påpeger, at det er bedst at opfatte dem som to separate traditioner, som forfatteren ikke har formået at flette sammen til et harmonisk hele. Dette adskiller teksten fra Sekthåndbogen, der netop var karakteriseret af den tætte relation mellem de to syndsopfattelser, jf. Collins 1997, 379. 
ske instans, der står bag personer som Jannes og hans bror, kan deres vildledende handlinger ikke tilskrives egen svaghed, men skal netop finde sin begrundelse uden for dem selv (CD 5,17-19; Davidson 1992, 183; Brand 2013, 224).

Belial er udstyret med tre net - hor, rigdom og besudling af helligdommen - hvilke er tekstens bestemmelser af synden. Med disse forleder Belial menneskene, hvorpå opdelingen af dem bliver en realitet, eftersom det er ikke-medlemmerne af sekten, der lader sig "indfange" af dem. Nettene fører først og fremmest til synd. Menneskene synder, fordi nettene får dem til at misforstå Guds bud. De genkender derfor ikke Belials snarer, men forveksler dem med retfærdighed (CD 4,16-17). Dette kan finde sted, eftersom perioden tilhører Belial, der har fået mandat fra Gud til at fordærve menneskene. Tiden er derfor karakteriseret ved ondskab, og det er afgørende for sekten at holde sig fri af dem, der er under påvirkning fra Belial. Det er et midlertidigt virke, som han er blevet tildelt, idet sekten venter en fremtidig forløsning, hvorefter hans magt er brudt (CD 3,20; 4,12-13; 6,14-7,4; Davidson 1992, 181-82; Brand 2013, 221-22).

Belial forleder ikke kun menneskene, for han optræder også, når syndere, der er fanget i et eller flere af hans net, skal tilintetgøres (CD 8,1-5). På den måde er det både ham, som fordærver menneskene, men også ham, som udfører straffefunktionen ved de eskatologiske begivenheder. Som tidligere nævnt er Belials virke i høj grad anvendt som forklaring på den sociale dualisme, der skiller sektmedlemmer fra udenforstående. Tekstens fokus ligger især på, hvordan ikke-medlemmer lader sig forlede af Belial, men det betyder ikke, at sekten fuldstændig undgår en negativ påvirkning fra ham. Belials straffefunktion er nemlig møntet både på dem, der står uden for sekten, og medlemmer, der har overtrådt budene (CD 8,1-3; 12,2-6; ibid., 225; 231). Derved rummer Damaskusskriftet en spænding, eftersom muligheden for frafald forekommer, samtidig med at teksten overordnet set er præget af en determinisme, hvor Guds kontrol gennemsyrer alt. Belial virker inden for denne ramme, og hans funktion illustrerer for sekten, hvorfor ikke-medlemmer vedbliver med at synde og afvise budene. Han fremstilles derfor som den ansvarlige instans for menneskenes fejltagelser gennem historien, hvor han har modarbejdet dem via deres egne ledere. Perioden er utvetydigt underlagt ham, eftersom han har formået at forlede menneskene, der nu ikke længere genkender de guddommelige bud (CD 4,16-17; 5,17-19; Davidson 1992, 178; 184; Brand 2013, 221; 224-26). 
De to tekster fra Qumran er ikke synderligt interesseret i englefal$\operatorname{det}^{29}$ fra 1 En 6-11 men har derimod en anden brug af onde engle. Selvom både Vægternes Bog og Jubilæerbogen er fundet blandt Dødehavsskrifterne, så overtager Sekthåndbogen og Damaskusskriftet ikke de to teksters syndsopfattels, men er optaget af den kosmiske kamp, som finder sted mellem to engle under Guds befaling. Dette kunne tyde på, at menigheden har haft en interesse i Vægternes Bog og Jubilæerbogen mht. til andre emner ( $\mathrm{fx}$ angående kalenderspørgsmål), mens synd er en problemstilling, som de i høj grad løste i relation til menighedens egne teologiske interesser.

Sammenfatning: Begge tekster opererer med en dualistisk verdensopfattelse, hvor Gud tildeles en uantastelig kontrol med verden, og hvor kampen mellem det gode og det onde udkæmpes af to engleinstanser. Sekthåndbogen kombinerer ideen om menneskets tilbøjelighed med ideen om de to ånder, og synd bestemmes som indre tendenser i mennesket, der udvirkes af Mørkets engel. På den måde påvirkes menneskets indre liv af ydre faktorer, og ideen om prædestination er en inkorporeret del af teksten, hvorfor mennesket ikke kan holdes ansvarlig for synden. I Damaskusskriftet karakteriseres synd som Belials net, og han forleder menneskene med det resultat, at de ikke genkender de guddommelige bud. Sektens medlemmer udskilles således fra ikke-medlemmer. Damaskusskriftet er præget af et deterministisk verdenssyn, men til trods for dette er frafald en mulighed, hvilket ligger som en spænding i teksten.

\section{Konklusion}

Jeg har i denne artikel forsøgt at vise, at der trods teksternes overensstemmelser forekommer så store teologiske forandringer i Jubilæerbogen, Sekthåndbogen og Damaskusskriftet, at indflydelsen fra Vægternes Bog mht. syndsspørgsmålet er begrænset.

Jubilæerbogen overtager englefaldets basiselementer, hvilket gør myten genkendelig, men en nærmere analyse af tekstens udgave har vist, at det er helt andre pointer, som bliver udledt deraf. Først og fremmest interesserer Jubilæerbogen sig ikke for syndens oprindelse, hvorfor dens inddragelse af englefaldet anvendes som forklaring på syndflodens komme og til at indføje ondskaben i den guddommelige orden. Teksten er præget af begrebsparret renhed/urenhed, og derfor holdes himlen fuldstændig adskilt fra englenes overtrædelser. Ligele-

29. Damaskusskriftet henviser kort til englefaldet i 2,17-19. 
des er teksten i højere grad optaget af at placere ansvaret for synd hos menneskene, og derfor kan de onde ånder først udøve deres indflydelse, hvis menneskene selv tager initiativ til at synde. Ånderne er underlagt Mastema, der har mandat fra Gud til at udøve sin indflydelse på jorden. På den måde foretager Jubilæerbogen vitale teologiske ændringer efter de interesser, som præger teksten, og derfor fremstiller den englefaldet i en udgave med andre fokuspunkter.

Selvom fundet af fragmenter fra Vægternes Bog blandt Dødehavsskrifterne tydeligt viser, at Qumranmenigheden kendte teksten, så overtager den ikke englefaldet som forklaring på syndens tilblivelse. Sekthåndbogen og Damaskusskriftet interesserer sig ikke for syndens oprindelse, men er derimod fokuseret på den synd, der foregår i nutiden, og den forklares ud fra faktorer, der virker både i og uden for mennesket. To engle er involveret i en kosmisk kamp, og teksterne er således præget af flere former for dualisme. Mørkets engel og Belial har begge onde ånder til deres disposition, men disse er ikke opstået i kølvandet på englefaldet, men har ligesom deres anførere eksisteret siden begyndelsen. Teksternes anvendelse af en repræsentant for ondskaben minder i højere grad om Jubilæerbogens brug af Mastema end om 1 En 6-11, hvor hverken Semjaza eller Azazel får et selvstændigt virke.

Analyserne har vist, at de tre tekster i høj grad anlægger deres egen vinkel på spørgsmålet om synd, og at kendskabet til Vægternes Bog ikke har betydet en overtagelse af dens version af englefaldet. Derimod har teksterne i flere henseender udarbejdet teologiske pointer, der står i kontrast til Vægternes Bog. 